IDEA - Studia nad strukturą i rozwojem pojęć filozoficznych XXVIII/2

Białystok 2016

\title{
TRANSLATORIUM
}

\author{
JEAN-JACQUES WUNENBURGER
}

\section{O NARODZINACH OBRAZU: OBECNOŚĆ CZY ZNIKANIE BYTU?}

Zjezyka francuskiego przetożyta
Marta Ples-Bęben

\section{Od tłumacza}

Podstawa przekładu: J.-J. Wunenburger, La naissance de l'image: présence ou disparition de l'être?, „Cahiers Gaston Bachelard” 1, 1998, s. 37-48. 


\section{Jean-Jacques Wunenburger}

\section{O narodzinach obrazu: \\ obecność czy znikanie bytu?}

Zdefiniowanie obrazu jako przedstawienia myślowego, tak uświadomionego, jak i nieuświadomionego, zakłada przeciwstawienie go spostrzeżeniu realnego przedmiotu. Podczas gdy spostrzeżenie stawia nas w relacji wobec przedmiotu, obraz - przeciwnie - zastępuje przedmiot, gdy ten nie jest już obecny lub gdy nigdy obecny nie był. Obraz, odnoszący się do bytu in absentia, nie jest zatem nigdy ujmowany jako to, co pierwotne, lecz jako pochodna innej, uprzedniej wobec niego rzeczy i ze względu na ten nadrzędny fakt poddawany jest osądowi. Ów byt stanowiący punkt odniesienia lub rzecz w sobie, może być realnością daną zmysłom empirycznie, ale może także stanowić jedność z naturą ponadempiryczną, z bytem niewidzialnym, dostępnym jedynie umysłowi. Na przykład u Platona, obraz został ujęty jako mimetyczna kopia Odniesienia (un Référent), czyli eidos, formy niematerialnej i duchowej ${ }^{1}$. W dwóch koncepcjach: realności zmysłowej i realności inteligibilnej, obraz jako ikona (eikon) zawsze jawi się jako nieobecność, brak, byt pomniejszy.

Chrześcijańska tradycja teologiczna będzie analizowała różnicę między bytem i obrazem zgodnie ze schematem uczestnictwa i pokrewieństwa: obrazikona powstaje w wyniku działania stwarzającego wzorca, tak jak Syn został spłodzony przez Ojca a Chrystus przez Boga; status obrazu oparty na jego pochodzeniu od stwarzającego wzorca (skąd „posłuszeństwo” Syna wobec Ojca)

\footnotetext{
${ }^{1}$ Platon, Państwo, przeł. W. Witwicki, księga X.
} 
umożliwia odwrotność - pozwala Bogu stać się widzialnym². Niezależnie od użytego języka, obraz nie ma nigdy ani prawdziwej substancjalności, ani własnej przyczynowości, zjawia się jedynie „po niewczasie”, gdy coś w pełni realnego ustępuje mu miejsca. Pojawienie się obrazu zakłada więc, że to, co istnieje naprawdę, czyli to, co realne, nie jest „wszystkim”, lecz wycofuje się, usuwa, by móc zostać przedstawionym przez obraz.

W tym kontekście pytania dotyczące przejścia od tego, co realne do obrazu, mnożyły się w toku dziejów. Pod jakimi warunkami to, co realne może powodować zaistnienie obrazu? Czy obraz powstaje jako negacja realności czy jako jej pochodna? A jeśli obraz zajmuje miejsce przedmiotu istniejącego, to jak ująć jego zdolność „zajęcia miejsca” tego, co realne? Czy obraz scalałby nieistnienie, pozostając w ścisłym sensie „irrealnym”? W jaki sposób może on jednak powodować pojawienie się i „efekt” przedmiotu istniejącego? Gdy natomiast przyzna się, że istnieje on w pewien sposób, to skąd bierze się jego zdolność do upominania się o istnienie, czasem wręcz do zjawiania się bardziej realnego, można powiedzieć „nadrealnego”, według wyrażenia przejętego przez Gastona Bachelarda $\mathrm{z}$ surrealizmu?

Wszystkie te pytania dotyczą w równej mierze natury, co funkcji i wartości obrazów dla podmiotu. Stoją w centrum wielu współczesnych teorii psychologicznych i psychoanalitycznych, często są podejmowane w filozoficznych analizach inspirowanych fenomenologią i hermeneutyką. Jednak były one już obecne i często podobnie formułowane $\mathrm{w}$ tradycyjnych spekulacjach metafizycznych oraz teologicznych. Zamiast tworzyć przegląd owych koncepcji, chcielibyśmy pokazać w jaki sposób filozoficzne ujęcie obrazu Gastona Bachelarda zbliża się do większości motywów interpretacyjnych tego zagadnienia. Nie wikłając się w synkretyzm, analizy Gastona Bachelarda zaświadczają wszakże o niewątpliwej ambiwalencji pełnej znaczeń i problemów, które można rozjaśnić i wzmocnić odnosząc je do innych, niekiedy pokrewnych interpretacji.

\footnotetext{
${ }^{2}$ Szerzej na temat teologii obrazu w chrześcijaństwie: por. J.-J. Wunenburger, Filozofia obrazów, przeł. T. Stróżyński, Gdańsk 2011.
} 
Ramy epistemologiczne i metafizyczne koncepcji obrazu Gastona Bachelarda w jej pierwszym okresie rozwoju bliskie są magicznemu idealizmowi niemieckich romantyków oraz teorii aktywnej wyobraźni okultystycznych myślicieli odrodzenia ${ }^{3}$, ujmujących obraz jako manifestację bytu a wyobraźnię jako moc zjednoczenia $z$ bytem. To dlatego Bachelard może powiedzieć: „Wyobraźnia nie zna nie-bytu"4. Według Bachelarda, Ja niespodzianie zapełniają obrazy, czyli nieobiektywne przedstawienia rzeczywistości wartościowane przez afektywne projekcje świadomego i nieświadomego psychizmu, przedstawienia obdarzone znaczeniami symbolicznymi otwierającymi dostęp do danej empirycznej (znaczeniami, których treść można w szczególny sposób rozjaśnić alchemiczną formułą czterech żywiołów Natury: wody, powietrza, ziemi i ognia). Bachelard, w ślad za Sigmundem Freudem, wiąże owe obrazy z nieświadomymi fantazmatami i ich libidalnymi obciążeniami ${ }^{5}$, jednak do kategorii obrazów zalicza także przedstawienia świadome, poprzedzające $\mathrm{w}$ większości przypadków akt spostrzeżeniowy. Dla Bachelarda obraz zdaje się być zatem pierwszy w sensie chronologicznym i logicznym, wcześniejszy od spostrzeżenia i pojęcia, choć jego aktualizacja psychiczna może następować w tym samym czasie, co percepcja. Obraz organizuje i przygotowuje percepcję, obciążając ją oczekiwaniami oraz wartościowaniami. Oto dlaczego może on zostać uznany za przyczynę pierwszych błędów osądu intelektualnego i „przeszkód epistemologicznych” opóźniających tworzenie wiedzy naukowej; nauka, by zyskać dostęp do prawdziwego poznania natury, musi więc ujarzmić obrazy aż do oczyszczenia, aż do prawdziwej psychoanalizy poznania obiektywnego ${ }^{6}$. Dlatego „prawdziwe” przedstawienie przedmiotów nie może dokonać się wyłącznie na drodze percepcji, zawsze skażonej obrazami - musi ona ustąpić miejsca abstrakcji naukowej „konstruującej” pojęcie zjawiska.

${ }^{3}$ Więcej na temat tych zagadnień: por. A. Faivre, Accès à l'ésotérisme occidental, Paris 1996.

${ }^{4}$ G. Bachelard, Poetyka marzenia, przeł. L. Brogowski, Gdańsk 1998, s. 191.

${ }^{5}$ Wpływ Freuda przejawia się przede wszystkim w jednym z pierwszych dzieł dotyczących poetyki: por. G. Bachelard, La Psychanalyse du Feu, Paris 1938; dalsze prace w większym stopniu będą podlegały wpływowi Junga.

${ }^{6}$ Por. G. Bachelard, Ksztattowanie się umystu naukowego. Przyczynek do psychoanalizy wiedzy obiektywnej, przeł. D. Leszczyński, Gdańsk 2002. 
Uczuciowa i symboliczna naddeterminacja pierwotnych obrazów staje się jednak procesem uprzywilejowanym w marzeniu poetyckim. Twórcza moc wyobraźni przejawia się w jej zdolności do przenikania w głąb obrazów, by je przekształcać i deformować. Wyobraźnia poetycka określa więc siebie przez taki stosunek do świata, który pozwala wzbogacać go dzięki wiązaniu nieświadomych obrazów podmiotu z ukrytymi w świecie znaczeniami. Marzenie na jawie zakorzenia się $\mathrm{w}$ nieświadomych obrazach podmiotu, nie oddzielając się od przedmiotów i łącząc się z nimi na zasadzie przeciwstawienia (marzenie animus) lub tworząc rodzaj zespolonej całości (marzenie anima) ${ }^{7}$. Wyobraźnia Bachelardowska rysuje się zatem przede wszystkim jako połączenie ze światem, stałe powiązanie z rzeczywistymi przedmiotami, udział w bycie rzeczy. Działając, wyobraźnia nieustająco przekształca - w relacji przedmiotowej - przedmiot $\mathrm{w}$ „nadprzedmiot", inaczej mówiąc: w przedmiot śniony. W ten sposób Bachelard odróżnia dwa nastawienia do świata: jedno, pokrewne poznaniu naukowemu konstytuuje abstrakcyjne poznanie przedmiotów wyłączając uczucia Ja i formując zdecydowane oddzielenie podmiot-przedmiot, drugie, bliskie wszechkosmicznemu oniryzmowi ustanawia rodzaj zgodności między Ja i Nie-ja.

Ta ontologiczna pozytywność jest jednak nie tyle własnością obrazu, co rezultatem działania dynamizmu, napędu całego bytu, który ujawnia się u Bachelarda jako wola mocy, taka jak analizował ją Friedrich Nietzsche. W sferze instynktów, człowieka określa nie tyle libido czy popęd śmierci - które nie są jednak negowane a jedynie relatywizowane - co conatus, impetus, pozytywna siła działająca, wyzwalająca wolę . Obraz okazuje się być u Bachelarda nieodłącznie związany z aktualizacją woli życia, co czyni tę koncepcję bliską stanowisku Schopenhauera9. Bachelardowski obraz staje się więc rodzajem ekspresji

${ }^{7}$ Terminologia zapożyczona od C.G. Junga. „Animus to projekty i troski, dwa sposoby na to, aby nie być obecnym dla samego siebie. Anima to marzenie, które żyje bieżącą szczęśliwością obrazów”. G. Bachelard, Poetyka marzenia, dz. cyt., s. 76.

8 „Nie dziwi zatem, że marzyć o obrazach materii - tak, po prostu marzyć o nich - oznacza wzmacniać wolę”. G. Bachelard, La Terre et les Rêveries de la volonté, Paris 1948, s. 23.

${ }^{9}$ Por. J. Libis, L'ombre de Schopenhauer dans l'oeuvre de Gaston Bachelard, „Le texte et l'idée. Cahiers du centre de recherches germaniques de l'Université de Nancy II" 10, 1995, s. 219 i nast. 
i uprzywilejowaną formą realizacji woli, w której nieświadome siły psychiczne łączą się z nieustannie zmieniającą się rzeczywistością.

Mówiąc językiem psychoanalizy, wydaje się, że u Bachelarda popęd, prowadzący do zniekształcania i przekraczania tego, co realne, bezustannie ogarnia Ja, utrudniając mu przystosowanie się do rzeczywistości. Nawet jeśli w pewnym stopniu Ja udaje się oddzielić od pierwotnego względem przedmiotowości (préobjectal) narcyzmu, jako że świat nieustannie narzuca się podmiotowi, to jednak nie udaje mu się ustalić relacji wobec przedmiotu, przyporządkować zasady przyjemności zasadzie rzeczywistości. Obraz pełni funkcję formy przejściowejw znaczeniu określonym przez Winnicotta ${ }^{10}$ - odrywającej ego od fantazmatu, ale także przenoszącej Ja poza przedmiot, co wprowadza rodzaj nowego wywłaszczenia (dépossesion) podmiotu, z zewnątrz niego samego. Oto dlaczego $\mathrm{w}$ marzeniu w mniejszym stopniu podmiot marzy o świecie, niż Świat marzy o sobie w indywidualności podmiotu ${ }^{11}$. Wyobraźnia psychologiczna staje się rodzajem odbiorczego „sensorium” dla wyobraźniowego zjawiania się Całości Świata.

Nawet bez bezpośrednich odniesień, Bachelardowskie ujęcie wyobraźni pozostaje $\mathrm{w}$ analogii do starożytnej tradycji myślowej, reprezentowanej przede wszystkim przez teozofię silnie inspirowaną neoplatonizmem i filozofią Plotyna. W tej perspektywie obraz i wyobraźnia są określane nie z punktu widzenia człowieka, ale Podmiotu absolutnego, nieskończonego, nazwanego Bogiem. Pryncypium wszystkich rzeczy jest ustanowione jako Jedno w filozofiach, w których brak idei osobowości boskiej (Plotyn) lub też jako „boskość” w tych, które wychodząc od chrześcijaństwa założyły ideę osobowego boga; Jedno lub „boskość" tworzą tożsamość nierefleksyjną, uprzednią wobec przedmiotowości tożsamość bytu, która odpowiada stanowi boskości sprzed Stworzenia lub sprzed powstania wielości.

Na przykład u Jacoba Boehmego pierwotnie niezdeterminowana „boskość” jest określana jako Abgrund lub Ungrund, czyli tożsamość nieświadoma siebie,

${ }^{10}$ Por. D.W. Winnicott, Jeu et Réalité. L'espace potentiel, trad. C. Monod, J.-B. Pontalis, Paris 1975.

${ }^{11}$ Por. G. Bachelard, Poetyka marzenia, dz. cyt., s. 197-242. 
analogiczna do otchłani symbolicznie nazwanej boską Ciemnością ${ }^{12}$. Absolut osiąga samorozwój jedynie tworząc obraz samego siebie, otwierając się na relację przedmiotową z lustrzanym odbiciem. To w zwierciadle, w podwojeniu siebie, boskość osiąga pierwszą samoświadomość. Dzięki zwierciadłu Bóg podwaja się i osiąga zdolność odniesienia swej istoty do tego, co odeń różne, by stać się dla siebie prawdziwym Podmiotem. Moment odbicia zbiega się z wyjściem Boga poza Ciemność, z wejściem w Światło, co wprowadza doświadczenie ujrzenia siebie w sferze widzialnego. W ujęciu Boehmego, tak jak w teologii dogmatycznej, stworzenie bytów skończonych (co w micie biblijnym zostało połączone z widzialnym stworzeniem Światła - fiat lux) musi następnie zostać zinterpretowane jako zmaterializowanie się obrazu w formie bytów utworzonych na „podobieństwo" Boga ${ }^{13}$. Stworzenie to nie tylko dokonanie się procesu, dzięki któremu boska tożsamość tworzy miejsce dla innobytu w przypadkowości człowieka i natury, pod warunkiem że ta przedmiotowa odmienność zachowuje się niczym obraz w rodzaju tego ze zwierciadła. Tworząc obraz inny od siebie, Bóg w taki sposób przenika do prawdziwej subiektywności lub Osoby, że człowiek, o ile jest Nie-Ja Boga stworzonym na jego obraz, zapewnia wyniesienie bytu absolutnego i uczestniczy w wypełnieniu jego istoty, inaczej mówiąc - jego „chwaty".

W ten sposób teozofia Boehmego karmi się metafizyką lustra a opisując stawanie się Boga, boskie samorództwo, wyprzedza w pewien sposób scenariusz ontogenezy, który odnajdziemy później w wielu teoriach psychologicznych i psychoanalitycznych: Podmiot nie może wykroczyć poza stadium narcystyczne inaczej, niż utwierdzając siebie w lustrzanym obrazie, w przedmiocie będącym jednocześnie Tym Samym i Innym. W ten sposób, realność ustanawia złączenie podobieństwa i odmienności, przez które Podmiot osiąga swój byt dokonany lub totalny. Jednak u Boehmego, jak u większości teologów monoteistycznych, in-

${ }^{12}$ Por. A. Koyré, La Philosophie de Jacob Boebme, Paris 1971.

${ }^{13}$ W Księdze Rodzaju, Bóg mówi: „Uczyńmy ludzi na Nasz obraz, podobnych do nas” (1.26). Cyt. za: Pismo Święte Starego i Nowego Testamentu. Najnowszy przektad z języków oryginalnych z komentarzem, przeł. Zespół Biblistów Polskich z inicjatywy Towarzystwa Świętego Pawła, Częstochowa 2008. 
ność przedmiotu, czyli Stworzenie, nie mogłoby stać się bytem autonomicznym. To bowiem umożliwiałoby narodziny absolutu na zewnątrz niego samego i prowadziłoby do dualizmu metafizycznego lub „dyteizmu”. Przeznaczenie lustrzanej realności, jaką jest Stworzenie, polega w istocie na odesłaniu do bytu boskiego, ostatecznie doprowadzającego odmienność świata do swej własnej, skończonej tożsamości. Oto dlaczego, zgodnie z teologią chrześcijańską, przeznaczenie świata tkwi w jego przekształcaniu się według planu zwanego Odkupieniem lub zbawieniem w eschatologiczną całość usuwającą u kresu czasu rozdział między Bogiem a jego stworzeniem.

Okazuje się więc, że filozoficzne koncepcje obrazu Bachelarda nie odbiegają znacząco od gałęzi teozoficznej o tyle, że podmiot psychologiczny utwierdza siebie jedynie w bezpośredniej relacji z zewnętrznym obrazem materialnym niczym z lustrem, w którym zawiązuje się połączenie subiektywności i obiektywności, wewnętrzności i zewnętrzności. Podobnie można by utrzymywać, że wyobraźnia u Bachelarda już w teraźniejszości unieważnia podział Ja/Nie-Ja na tych samych zasadach, na których Bóg w czasach apokaliptycznych wciela zewnętrzne i niedoskonałe stworzenie, by odnowić w samym sobie stan uogólnionej doskonałości.

Niemożliwe jednak, by to podstawowe odczytanie Bachelardowskiej myśli było tak proste i jedyne możliwe. Nawet jeśli na pierwszy rzut oka wyobraźnię zdaje się określać siła wznosząca, która poszerza sferę Ja i sprawia, że uczestniczy ono w przedmiotach przeobrażanych przez rozbudzone w marzeniu wartości metafizyczne, ponadzmysłowe, to jednak współtworzy ona także obszary w większym stopniu niejasne, gdzie przy jej udziale pojawiają się formy mniej żywotne i twórcze. W wielu fragmentach swego dzieła Bachelard zdaje się analizować obraz w sposób bardziej subtelny i mroczny. Moc obrazu, skierowana ku „nad-przedmiotowi”, pobudzająca dynamikę marzenia, odsłania bowiem w pewnych doświadczeniach inny wymiar, odmiennie złączony z próżnią, brakiem, negacją. 
Sam Bachelard przyznaje, że na zawsze naznaczyło go to, czego doznał wspinając się po schodach katedry w Strasburgu ${ }^{14}$. Nagły zawrót głowy odebrał mu przytomność, po uderzeniu powietrza, które przeniknęło także do wyobraźni nastąpił upadek w pustkę, zwrot skierowany nie wzwyż, ale ku głębi. W tym pouczającym przeżyciu niewątpliwie można dostrzec potwierdzenie prostej polaryzacji obrazu zgodnej ze schematami sensomotorycznymi, nawykowymi wzorcami porządkującymi nasze aktywności i ich wyobrażenia zgodnie z podziałem na górę i dół. Pozytywnym obrazom, w których rzeczy mają wyraźnie uprzywilejowaną pozycję, zostają w ten sposób przeciwstawione obrazy regresywnego zejścia. Skądinąd Gilbert Durand w swej typologii struktur wyobraźni utrzyma Bachelardowską lekcję i ustanowi odruch jednym z trzech przeciwstawnych systemów stawania się obrazów ${ }^{15}$.

Bezsprzecznie należy jednak pójść dalej. Doświadczenie zawrotu głowy i związanego z nim szeregu mrocznych obrazów pokazuje Bachelardowi, że byt nie ogranicza się do siły twórczej rozbudzającej pogodny oniryzm, ale że w jego wnętrzu, ponad źródłową próżnią mieści się zagłębienie bytu uzasadniające jego kruchość, samotność i niepokój. Chodziłoby więc o „zgliszcza bytu, zgliszcza Dasein znane także fizycznie, na ile to możliwe...” i dalej: „Nasza nieświadomość jest niczym wydrążona przez wyobrażoną czeluść. Wszystko może w nas uderzyć, wszystko może nas dosięgnąć, by wywołać samounicestwienie" ${ }^{\text {"16. Pod }}$ pewnymi względami siła napędowa, wola niosąca byt ku światu styka się tu z niedomiarem bytu przywodzącym na myśl popęd destrukcyjny, popęd śmierci. Należałoby tu zatem utrzymać, że popęd śmierci nie zmierza bezpośrednio ku zewnętrznym obiektom by je zniszczyć lub usunąć, ale że kieruje się on przede wszystkim przeciwko samemu podmiotowi.

W ten sposób wyobraźnia oniryczna nabrałaby nowego znaczenia: przez swą moc twórczą zmierzałaby do przeciwstawienia się popędowi śmierci, do zasypania otwierającej się wewnątrz ontologicznej pustki. Dodatkowy sens, który wyobraźnia nadaje rzeczom wykraczając poza ich postrzeganie, ciepło wnoszone

\footnotetext{
${ }^{14}$ Por. G. Bachelard, La Terre et les Rêveries de la volonté, dz. cyt., s. 344 i nast.

${ }^{15}$ Por. G. Durand, Les Structures anthropologiques de l'imaginaire, Paris 1984.

${ }^{16}$ G. Bachelard: La Terre et les Rêveries de la volonté, dz. cyt., s. 347 i 351.
} 
przez obraz do świata, co tworzy z niego Hiper-podmiot, jest w istocie jedynie dążeniem do ukrycia bądź uciszenia ślepej siły działającej w głębi Ja. W marzeniu na jawie, wyobraźnia stawałaby się zatem zbawienną a nawet podstawową (vitale) funkcją psychiczną nie tyle ze względu na pierwotne poczucie szczęścia, które podsyca dzięki obrazom, co wskutek zdolności do ukrywania, maskowania nicości bytu przez tworzenie jego naddatku: „Marzenie zespala byt wokół swego marzyciela. Stwarza złudzenie, że jest czymś więcej, niż jest. W ten sposób na owym mniej-byciu, którym jest stan rozluźnienia i gdzie kształtuje się marzenie, zarysowuje się relief, który poeta potrafi rozdąć, czyniąc z niego więcej-bycie"17. Wytwarzanie obrazów to wytyczanie pierwszej drogi prowadzącej do zniesienia pierwotnego lęku, wynikającego z ontologicznego non-sensu. W ten sposób, przez pesymizm o niewątpliwej Schopenhauerowskiej inspiracji, Bachelard wprowadza do pozornej pozytywności wyobraźni źródłową negatywność. W porządku fenomenologicznym obraz jest bezsprzecznie pierwszy, jednak w szeregu ontologicznym zajmuje tylko drugą pozycję. Skoro początek ustanawiają wewnętrzne Ciemności zapowiadające brak bytu, to byt wskazuje na to, co pochłania nas w nieokreśloności i śmierci, doświadczanych przez Bachelarda w marzeniu nocnym: „Marzenie senne rozprasza nasz byt na widma dziwacznych bytów, które nie są już nawet naszymi własnymi cieniami [...]. W głębiach tych, w intymności, ocieramy się o nicość, o naszą nicość [...]. Wszystkie te wygaszenia $\mathrm{w}$ ciemności nocy zbiegają się w nicości naszego bytu. W ostatecznym rozrachunku absolutne sny pograżżąą nas w świecie Nicości”18. W ten sposób Bachelardowska koncepcja wyobraźni odnajduje jej subtelne dążenia, by - zagęszczając przedmioty - nieustannie zaklinać niedomiar podmiotu.

Poprawka wprowadzona przez Bachelarda do jego aktywnego ,imaginaryzmu" świadczy więc o niepowstrzymanym wymiarze negatywności towarzyszącej obrazowi. Jak wobec tego wypowiedzieć połączenie pozytywności i negatywności, bytu i nicości, pełni marzonego przedmiotu i niedomiaru podmiotu? Jak określić stanowisko Bachelarda względem tych ujęć wyobraźni, które odnoszą ją do dialektyki życia i śmierci?

\footnotetext{
${ }^{17}$ G. Bachelard, Poetyka marzenia, dz. cyt., s. 174.

${ }^{18}$ Tamże, s. 166-167.
} 
W pewnym sensie Bachelard okazuje się być bliższy pesymistycznej a nawet nihilistycznej tradycji myśli niemieckiej (od Schopenhauera do Heideggera), niż współczesny mu Francuz - Jean-Paul Sartre. Dla Sartre’a wyobraźnia jest intencją świadomości, która przez neantyzację chce umknąć rzeczywistości, jej masywnej i alienującej naturze. Powieść Mdtości pokazuje, że rzeczywistość w samym swym istnieniu przedstawia się jako lepka magma atakująca Ja, opanowująca je i wykluczająca $z$ samego siebie ${ }^{19}$. Od tych egzystencjalnych mdłości nie można uciec inaczej niż przy pomocy wyobraźni, wyzwalającej nas dzięki świadomości odrzeczywistniającej. Według Sartre’a, wyobraźnia jest zatem negacją świata obiektywnego. Obraz to tylko quasi-obserwacja, w której zmierzamy do danej spostrzeżeniowej jako nieobecnej ${ }^{20}$. Zachwyt, jaki w Sartrze wywołuje zniknięcie świata, ucieczka poza rzeczywistość, powraca w jego fenomenologicznej analizie emocji. I tak, zachowanie wynikające ze strachu, emocji przejawiającej się tu w usuwaniu niebezpieczeństwa, polega na unicestwianiu świata, na magicznym nicościowaniu go. W miejsce zmiany stosunku wobec przedmiotu, z czym mamy do czynienia w przypadku wyobraźni, w emocji dokonuje się symetryczne zniknięcie Ja ${ }^{21}$. Obraz i zniknięcie ujawniają zatem tę samą negację danej spostrzeżeniowej. Skądinąd ów negatywny stosunek świadomości do świata znajduje u Sartre'a tym pełniejsze uzasadnienie, że świadomość w swej istocie przedstawia się jako czysta nicość. Analizy otwierające Byt i nicość pokazują, że o ile w-sobie rzeczy, przedmioty, dają się uchwycić jako pełna, nieprzejrzysta totalność, o tyle świadomość zjawia się na zasadzie kontrastu jako to, co nie jest, jako nic - niczym otwór powietrzny wewnątrz orbity. „Tak więc nicość jest tą dziurą w bycie, tym skokiem bytu-w-sobie w stronę jaźni (soi), skokiem, dzięki któremu ustanawia się byt-dla-siebie [...]. Nicość jest kwestionowaniem bytu przez byt"22.

${ }^{19}$ Por. J.-P. Sartre: Mdtości, przeł. J. Trznadel, Warszawa 1974; Kraków 2005.

${ }^{20}$ Por. J.-P. Sartre, Wyobrażenie. Fenomenologiczna psychologia wyobraźni, przet. P. Beylin, Warszawa 1970; 2012.

${ }^{21}$ Por. J.-P. Sartre, Szkic o teorii emocji, przeł. R. Abramciów, Kraków 2006.

${ }^{22}$ J.-P. Sartre, Byt i nicość. Zarys ontologii fenomenologicznej, przeł. J. Kiełbasa, P. Mróz i in., Kraków 2007, s. 121-122. 
Jeśli wyrażone w ostatnim zdaniu przekonanie, które Sartre dzieli ze współczesnym egzystencjalizmem nihilistycznym (w szczególności z Heideggerem), częściowo zawiera się w drugiej filozofii obrazu Bachelarda, to idea wyobraźni rozumianej jako aktywna neantyzacja przeciwnie - jest mu obca. Wyobraźnia u Sartre’a uczestniczy w wolności jedynie przez bezwzględny stosunek do świata, w którym neantyzacja nie jest nigdy daleka od destrukcji. U Bachelarda przeciwnie, obraz nie niszczy a raczej jest tym, co musi ukryć śmierć, kres bytu, który zostaje wyparty w głąb nieświadomości. Krótko mówiąc, obraz chroni nas przed zgubnymi siłami. Bachelardowska wyobraźnia pozostaje przede wszystkim oniryczną mocą złączenia z przedmiotami, umiłowaniem rzeczy, podczas gdy u Sartre'a odsuwa nas ona od rzeczywistości i zamyka w masochistycznej subiektywności. Jeśli zatem Sartre ujął stosunek obrazu do nicości w sposób bardziej zamknięty i usystematyzowany niż Bachelard, to jednak nie wydaje się, by mógł zdawać sobie sprawę z wyzwalającej dynamiki obrazów i z mocy twórczej wynikającej z samej ich obecności w świecie.

W tym kontekście sugestywne psychoanalityczne rozjaśnienie daje interpretacja Massimo Fagioli, pozwalająca wejrzeć głębiej w zagadnienie pustki jako warunku pojawienia się obrazu ${ }^{23}$. W sposób bliski Sartre’owi, zastępując jednak fenomenologię filozoficzną metodą psychogenetyczną, Fagioli rozważa obraz jako pierwotną „zanikającą fantazję”, towarzyszącą przejściu płodu z matczynej nocy ku światłu widzialności ${ }^{24}$. Wyobraźnia niemowlęcia z początku przejawia się jako popęd destrukcyjny, unieważniający istnienie przedmiotu jako możliwego do ujrzenia w pełnym świetle a następnie cofa się do stadium płodowego, w którym relacja z przedmiotem nawiązuje się wciąż na ślepo, pozbawionym wzroku aparatem zmysłowym. Proces „zanikającej fantazji” nie ogranicza się jednak do tego regresywnego stadium. Zaszczepia się on w nieświadomości na popędzie miłości, na libido, przekształcającym się odtąd w twórczą moc nowego wyobrażenia, które towarzyszy rozwojowi podmiotu. Wyobraźnia jest więc ujęta jako proces dialektyczny jednoczący popęd destrukcji i popęd miłości, Tanatos

\footnotetext{
${ }^{23}$ Por. M. Fagioli, Instinto di morte e Conoscenza, Roma 1991.

${ }^{24}$ Stąd istotne miejsce Freudowskiej analizy dziecięcej zabawy. Por. S. Freud, Poza zasada przyjemności, przeł. J. Prokopiuk, Warszawa 1975; 1976; 1994; 1997; 2000; 2005.
} 
i Eros. W tej wysublimowanej analizie przejawia się troska o połączenie w wyobraźni negacji i afirmacji, unieważniania i tworzenia, dzięki czemu znaczenie jednego bądź drugiego nie jest w niej jednostronnie wyolbrzymiane, co ma miejsce w przypadku Bachelarda lub Sartre'a.

Wracając do intuicji Bachelardowskich można jednak spytać, czy tak Sartre, jak i Fagioli nie przeszacowują popędu lub dążenia do anihilacji przedmiotu dla świadomości, by stała się ona empiryczna bądź transcendentalna. $Z$ pewnością za ich zasługę należy uznać przypomnienie, że rzeczywistość w swej widzialności, w tej mierze, w której jest warunkiem inności podmiotu, narzuca przemoc i ukazuje się jako zagrożenie, a także że obraz może pojawić się tylko tam, gdzie rzeczywistość przestaje być ujmowana jako totalność, jako substancjalność. Podmiot całkowicie ujarzmiony przez rzeczywistość, czyli zupełnie do niej dostosowany, dla którego rzeczywistość stanowiłaby całość świadomości, zostałby pozbawiony tak obrazów, jak i wyobraźni. Obraz ustanawia różnicujący uskok, wyzwalające przesunięcie, które równoważy bezduszność rzeczywistości i łagodzi jej ciężar. Czy jednak koniecznie trzeba zawsze docierać aż do stadium zaniku? I jeszcze, jeśli rzeczywistość zostanie definitywnie zanegowana, to jak przywrócić obrazowi moc twórczą, pozwalającą mu, jak to pokazuje Bachelard, otworzyć nam drogę do „surrealnego”?

Przede wszystkim, na ile rzeczywiście zniknięcie przedmiotu z pola widzenia jest potrzebne, by obraz mógł się pojawić? Lub przynajmniej, co to znaczy: „zniknąć”? Można tu podążyć za dwiema interpretacjami: w pierwszej wystarczy, by przedmiot opuścił obszar widzialności, tak by podmiot zastąpił go swym obrazem-wspomnieniem, jednak bez zanegowania samego przedmiotu, bez zneantyzowania go, skoro wciąż jest on obecny, choć dla mnie niewidoczny ${ }^{25}$. Co więcej, zniknięcie nawet nie przekształciło przedmiotu, obraz powinien więc przywrócić go takim, jakim uchwyciło go spojrzenie. W drugiej interpretacji przeciwnie, należałoby założyć, że sam przedmiot, taki jak dany jest spojrzeniu, przedstawia się jako niedokończony, niedoskonały, niestały - pojawiający się

${ }^{25}$ Por. L. Couloubaritsis, Dire invisible, [w:] tegoż: La part de l'oeil, Bruxelles 1987, s. 53 i nast. oraz tenże: L'art comme mode d'accès à l'invisible, [w:] tegoż: La part de l'oeil, dz. cyt., s. 127 i nast. 
i znikający jednocześnie. Nawet w swym istnieniu zjawiskowym przedmiot uwidaczniałby, że nie jest prawdziwie w-sobie, że nie jest absolutnie rzeczywisty, że zachowuje w sobie grę form, pojawień, zmiennych własności. Obraz powstawatby więc nie jako unieważnienie bytu, lecz jako jego uzewnętrznienie w zjawianiu się, nawet poza jego pojawieniami. Obraz nie musiałby zastępować przedmiotu, ale prowadziłby przedmiot konkretny, przypadkowy, niestały ku przedmiotowi zobrazowanemu - wzorcowemu, eidetycznemu, stałemu.

$\mathrm{Na}$ tym ostatecznie polega proces założony przez Bachelarda, według którego obraz wzbogaca, dopełnia realności empiryczne dane w spostrzeżeniu. Przedmiot nie znika w wyobraźni, jest ona raczej tym, co staje na drodze owemu zniknięciu, co sprzeciwia się rozproszonej płynności przedmiotów, co wstrzymuje erozję czasu. W tej perspektywie należałoby więc powiedzieć, że obraz może pojawić się tylko tam, gdzie jego punkt odniesienia traci samowystarczalność i umiera dla samego siebie, by odrodzić się w obrazie stanowiącym jego kontynuację. Antycypację takiego ujęcia można odnaleźć już w chrześcijańskiej teologii wcielenia, którą swobodnie odczytujemy, podporządkowując ją kwestii związków między rzeczywistością a obrazem ${ }^{26}$. Przed nadejściem Syna Bożego, czyli wydarzeniem fundującym chrześcijaństwo, Bóg tworzy rzeczywistość w sobie i przez siebie, bez tego, co inne oraz widzialne. By się uzewnętrznić, by pojawić się dla świadomości, musi - jako Bóg-Ojciec - zrodzić obraz samego siebie, gdyż jedynie obraz pozwala człowiekowi prawdziwie ujrzeć Boga w sobie niewidzialnego. Święty Paweł dostrzegł - co zostało potem podjęte przez Lutra i współczesną teologię „kenotyczną”, odróżniających się w ten sposób od teologów spekulatywnych - że uobecnienie się Boga w rzeczy innej niż on sam, przemiana Ojca w Syna, przemiana Boga w Człowieka-Boga, wymaga od Boga „usunięcia” samego siebie, by zrobić miejsce dla tego, co inne niż on $\operatorname{sam}^{27} . \mathrm{Na}$ tym polega teoria „kenozy”, w której Ojciec obrazu umiera dla siebie, by w rzeczy różnej od siebie zrodzić swój obraz, czyli ludzkość. Zostać przekształconym w obraz znaczyłoby więc, że przedmiot w sobie (Bóg) może wejść w światło wi-

${ }^{26}$ Szerzej na ten temat: Por. J.-J. Wunenburger, L'image au-delà de l'être et du néant, [w:] Image et Valeur. Cabiers du Groupe d'études spirituelles comparées, Milano 1994, s. 27-38.

${ }^{27} \mathrm{Tę} \mathrm{analizę} \mathrm{odnajdziemy} \mathrm{także} \mathrm{w} \mathrm{rdzeniu} \mathrm{dialektyki} \mathrm{Heglowskiej.}$ 
dzialności i pozostać w nim tylko wtedy, gdy zrezygnuje ze swej czystej istotowości i uwidoczni się w obrazie. To zatem odniesienie, absolutna realność, tożsamość bez inności, jeszcze-nie obrazu byłoby przestrzenią znikania, unicestwiania, dzięki któremu obraz mógłby się wyłonić. Negatywność tkwi więc nie tyle w obrazie, co w rzeczywistości. Jedynie bowiem realność, która opróżnia się $\mathrm{z}$ siebie samej nie będąc samowystarczalną, nie utrzymując się w swym bezpośrednim „byciu-tu”, lecz dążąc do bycia w pełni widzialną, może dać początek swemu obrazowi. Obraz istnieje zatem tylko dlatego, że rzeczywistość nie daje się bez niego zobaczyć w pełni. W tej perspektywie geneza obrazu odsłania więcej $z$ teorii bytu a więc $z$ ontologii, niż $z$ teorii podmiotu czyli psychologii.

Jednak symboliczna logika wcielenia teologicznego zmierza dalej. Według założycielskiej historii, w dalszej kolejności obraz powinien zniknąć, by zaistnieć mogła realność absolutna, w pełni dokonana. Stąd przeznaczenie Syna Bożego by doświadczyć Pasji, przekroczyć śmierć ku zmartwychwstaniu i ponownie złączyć się z Ojcem. W ten sposób w poranek wielkanocny, po zniknięciu z opuszczonego grobu, Chrystus zmartwychwstaje przed swym przeobrażeniem i wejściem na prawicę Ojca ${ }^{28}$. Cóż można dodać jeśli nie to, że obraz nigdy nie może zostać zastąpiony przez swe odniesienie, nie może sam stać się w pełni rzeczywistością, lecz że istnieje jedynie w tej mierze, w której doprowadza do swego źródła. Stąd obraz - nie będący negacją rzeczywistości, jej przeciwieństwem - stanowi jej zapośredniczenie. Wyobraźnia byłaby zatem złożonym procesem śmierci-odrodzenia: rzeczywistość umiera dla siebie, co pozwala ukazać się jej obrazowi wizualnemu, który sam, zamiast zostać uchwycony jako rzeczywistość musi z kolei umrzeć, by podmiot uchwycił całkowitą realność. Znikanie w czasie teraźniejszym dotyczy obrazu a nie przedmiotu i dokonuje się nie po to, by ustanowić przedstawienie, ale by zyskało ono zakończenie, kres. Każdy obraz musi ustąpić miejsca innemu obrazowi lub nie-obrazowi, jeśli nie chce się przekształcić w obraz zobiektywizowany, czyli w idola. W tej perspektywie teologiczno-metafizycznej, śmierć obrazu nigdy nie jest definitywną utratą, zniknię-

${ }^{28}$ Por. jako ilustrację obraz Fra Angelico przedstawiający zmartwychwstanie Chrystusa, który znajduje się w klasztorze San Marco we Florencji. Kobiety spoglądają na nim do pustego grobu, co stanowi symbol przeobrażenia obrazu w rzeczywistość w sobie. 
ciem na zawsze, powrotem w ciemności. Dla bytu w obrazie śmierć to jedynie sposób, by zniknąć przed ponownym narodzeniem. Śmierć i życie następują zatem po sobie w nieustannej, nieskończonej grze, w której rzeczywistość przechodzi w obraz a obraz w rzeczywistość. Jedynie w tej dialektycznej wymianie obraz może być prawdziwie twórczy i pozwolić podmiotowi, by nigdy nie żył jednostronnie: tylko w obrazie, bądź tylko w rzeczywistości, co w każdym przypadku skazywałoby go na szaleństwo.

Konkludując: ze względu na sam fakt niejednoznaczności i zmienności poglądów Bachelard ostatecznie zdaje się przybliżać do tajemnicy obrazu: ani nie rodzi się on, ani nie trwa wyłącznie w obecności rzeczy, bądź jedynie w jej całkowitej nieobecności, ale w swobodnej grze obecności-nieobecności, widzialnego-niewidzialnego. Analizy Bachelarda, rozjaśnione przez tło teozoficzne i teologiczne wyprzedzające wiele współczesnych debat na temat obrazu, skłaniają do uznania, że rzeczywistość nie wystarcza samej sobie, ale musi być w pełni postrzegana przez zobrazowane przedstawienie. W sferze obrazu nie można rozdzielać aspektu negatywnego i aspektu pozytywnego - obydwa, pozostając we wzajemnej relacji, kształtują bowiem przestrzeń gry umożliwiającej powstanie obrazu. 